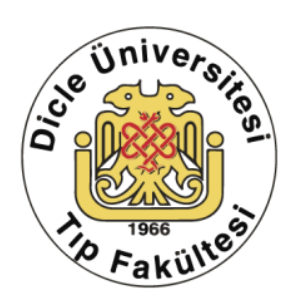

\title{
Seroprevalences of Hepatitis B and Hepatitis C among healthcare workers in Tire State Hospital
}

\author{
Gokcen Gurkok Budak ${ }^{1}$, Nalan Gülenç ${ }^{2}$, Elife Özkan ${ }^{3}$, Rıfat Bülbül ${ }^{4}$, Caner Baran ${ }^{5}$ \\ 1 Tire State Hospital, Clinic of Infectious Disease and Clinical Microbiology, Izmir, Turkey ORCID: 0000-0002-6317-7685 \\ 2 Tire State Hospital, Clinic of Infectious Disease and Clinical Microbiology, Izmir, Turkey \\ 3 Tire State Hospital, Department of Biochemistry, Izmir, Turkey \\ 4 Bilecik State Hospital, Department of Medical Microbiology, Izmir, Turkey \\ 5 Tire State Hospital, Department of Medical Microbiology, Izmir, Turkey \\ Received: 02.05.2017; Revised: 13.07.2017; Accepted: 27.07.2017
}

\begin{abstract}
Objective: The risk of infection with HBV and HCV in healthcare workers has been increased as risks such as contact with the blood or open wound of the infected people. The aim of the study was to investigate the seroprevalence of hepatitis B virus (HBV) and hepatitis C virus (HCV) infections among healthcare working at Tire State Hospital.

Methods: Screening records of total 518 hospital personnel working in the Tire State Hospital between January 2012 and April 2017 were retrospectively reviewed. HBsAg, Anti-HBs and Anti HCV tests on the blood samples obtained for screening were performed in our laboratory using Siemens advia centaur XP chemiluminescence technique.

Results: Between January 2012 and April 2017, a total of 518 health workers, ranging in age from 18 to 63 working in the State Hospital, were evaluated in infectious diseases and clinical microbiology clinics.

Our personnel were negative for Anti-HBs 61 (11.8\%) and anti-HBs positivity was detected in $457(88.2 \%)$ of the obtained samples, $6(1.2 \%)$ of these personnel were positive for HBsAg. It was detected that two cleaning personnel and a nurse were positive for anti-HCV.

Conclusion: Hospital workers should be screened for HBV and HCV and individuals without HBV vaccination should be vaccinated. In our country, HBsAg positivity in healthcare workers has decreased especially in recent years. Nevertheless, healthcare workers are still under the risk of HBV and HCV. Therefore, it is important to keep and review the records of hospital workers regularly.
\end{abstract}

Keywords: Hepatitis B virus, hepatitis C virus, healthcare workers, seroprevalence

DOI: $10.5798 /$ dicletip. 339008

Yazışma Adresi / Correspondence: Gokcen Gurkok Budak, Tire State Hospital, Clinic of Infectious Disease and Clinical Microbiology, Izmir, Turkey e-mail: gokcenbudak@gmail.com 


\section{Tire Devlet Hastanesi sağlık çalışanlarında Hepatit B ve Hepatit C Seroprevalansı}

\section{Özet}

Amaç: Sağlık çalıșanlarında HBV ve HCV enfeksiyonu riski, enfekte kișilerin kanı veya açık yaraları ile temas nedeniyle artmıștır. Çalışmamızın amacı, Tire Devlet Hastanesinde çalışan sağlık çalışanları arasında hepatit B virüsü (HBV) ve hepatit C virüsü (HCV) enfeksiyonlarının seroprevalansının araştırılmasıdır.

Yöntemler: Ocak 2012 - Nisan 2017 tarihleri arasında Tire Devlet Hastanesi'nde çalışan 518 hastane personelinin tarama kayıtları retrospektif olarak incelendi. Tarama için elde edilen kan örnekleri, laboratuvarımızda Siemens advia centaur XP kemilüminesans tekniği kullanılarak HBsAg, Anti-HBs ve Anti HCV testleri gerçekleştirildi.

Bulgular: Ocak 2012-Nisan 2017 tarihleri arasında, Tire Devlet Hastanesi'nde yaşları 18-63 arasında değişen, enfeksiyon hastalıkları ve klinik mikrobiyoloji kliniğinde değerlendirilen toplam 518 sağlık çalıșanı çalıșmaya dahil edildi. Çalışanlarımızdan elde edilen kan örneklerinin 61'inde $(\% 11,8)$ Anti-HBs negatifti ve 457'sinde $(\% 88,2)$ antiHBs pozitifliği tespit edildi, bu personelin 6 'sında $(\% 1,2)$ HBsAg için pozitifti. Anti HCV için iki temizlik personeli ve bir hemşire pozitif saptandı.

Sonuç: Hastane çalışanları, HBV ve HCV için taranmalı ve HBV aşısı olmayan bireyler aşılanmalıdır. Ülkemizde sağlık çalışanlarında HBsAg pozitifliği özellikle son yıllarda azalmıştır. Bununla birlikte, sağlık çalışanları halen HBV ve HCV enfeksiyonu için risk altındadır. Bu nedenle, hastane çalışanlarının kayıtlarını düzenli olarak tutmak ve gözden geçirmek önemlidir.

Anahtar kelimeler: Hepatit B virüsü, hepatit C virüsü, sağlık çalışanı, seroprevalans

\section{INTRODUCTION}

The risk of infection with HBV and HCV in healthcare workers has been increased as the risks such as contact with the blood or open wound of the infected people ${ }^{1}$. HBV and HCV are the most common causes of chronic hepatitis, cirrhosis and hepatocellular carcinoma in the world resulting in high morbidity and mortality ${ }^{2}$. According to the reports by World Health Organization (WHO), more than 85 million healthcare workers around the world are exposed to injuries by contaminated medical devices ${ }^{3}$. It is reported that the rate of HBV carriers in Turkey is 3-7\% and this rate is about 2 times higher among the healthcare workers ${ }^{4}$. However, particularly raising the rate of vaccination of individuals non-immunized according to the screening may reduce the risk of getting $\mathrm{HBV}$ infection among the workers ${ }^{5}$. In this study, it has been aimed to detect the seroprevalences of hepatitis $B$ and hepatitis $\mathrm{C}$ of healthcare workers working at Tire State Hospital to remind once again the importance of vaccination of unvaccinated individuals susceptible to hepatitis B.

\section{METHOD}

Screening records of total 518 hospital workers working in the Tire State Hospital between January 2012 and April 2017 were retrospectively reviewed. HBsAg, Anti-HBs and Anti HCV tests on the blood samples obtained for screening were performed in our laboratory using Siemens advia centaur XP chemiluminescence technique. Positive results were checked for the second time with the same kit. The obtained data were evaluated using the number and percentage calculations.

\section{RESULTS}

A total of 518 healthcare workers, ranging in age from 18 to 63 working in the State Hospital, who presented to in the clinics of infectious disease and clinical microbiology at Tire State Hospital between January 2012 and April 2017 were included in the study. Demographics and distribution of healthcare workers are provided in Table 1. 
Our hospital workers were negative for AntiHBs 61 (11.8\%) and anti-HBs 457 (88.2) positivity was detected in 518 of the obtained samples, $6(1.2 \%)$ of these personnel were positive for HBsAg. It was detected that two cleaning personnel and a nurse were positive for anti-HCV. (Table 2).

Table 1: Demographic Characteristics and Distribution of Healthcare Workers

\begin{tabular}{|l|c|c|}
\hline Data & Number & (\%) \\
\hline Woman/man & $281 / 237$ & $54.2 / 46.8$ \\
\hline Doctor & 78 & 15.1 \\
\hline Nurse & 174 & 33.6 \\
\hline Anesthesia technician & 27 & 5.2 \\
\hline Cleaning staff & 102 & 19.7 \\
\hline Other & 137 & 26.4 \\
\hline
\end{tabular}

Table 2: Anti-HBs, HBsAg and Anti-HCV Distribution of Seropositivity

\begin{tabular}{|l|c|c|c|}
\hline Professions & $\begin{array}{c}\text { Anti-HBs } \\
\text { Number (\%) }\end{array}$ & $\begin{array}{c}\text { HBsAg } \\
\text { Number ( \%) }\end{array}$ & $\begin{array}{c}\text { Anti-HCV } \\
\text { Number \% }\end{array}$ \\
\hline Doctor (n:78) & $72(92.3)$ & $1(1.3)$ & $0(0)$ \\
\hline Nurse (n:174) & $158(90.8)$ & $2(1.1)$ & $1(0.6)$ \\
\hline $\begin{array}{l}\text { Anesthesia } \\
\text { technician (n:27) }\end{array}$ & $23(85.2)$ & $0(0)$ & $0(0)$ \\
\hline $\begin{array}{l}\text { Cleaning staff } \\
\text { (n:102) }\end{array}$ & $82(80.4)$ & $2(1.9)$ & $2(2)$ \\
\hline Other (n:137) & $122(89.1)$ & $1(0.7)$ & $0(0)$ \\
\hline Total (n:518) & $457(88.2)$ & $6(1.2)$ & $3(0.6)$ \\
\hline
\end{tabular}

\section{DISCUSSION}

The global epidemiology of HBV infection has been described according to three categories of endemicity depending on the proportion of the population that is seropositive for HBsAg, our country is in the area of intermediate endemicity ${ }^{6}$. Seroprevalence of HBsAg in blood donors (n: 14354 ) was reported as $2.9 \%$ in our country ${ }^{7}$. Altındiş et al. in two separate studies in healthy blood donors performed in Afyon, they showed that HBsAg seropositivity decreased from $8.7 \%$ to $1.3 \%$ in years ${ }^{8,9}$. Tekay et al. study reported 5.1\% HBsAg positivity in
Turkey ${ }^{10}$. In recently study, HBsAg positivity was reported as $1.6 \%$, which was a low rate, for the study conducted in healthcare workers in our country ${ }^{11}$. Similarly, we found in healthcare workers that HBsAg seropositivity was $1.2 \%$ in our study.

In the studies performed in healthcare workers, anti-HBs positivity was detected as $81.4 \%$ by Bosnak et al. ${ }^{12}$, as $73.4 \%$ by Akcall et al. ${ }^{13}$ and as $86 \%$ by Korkmaz et al. ${ }^{14}$. That rate was found as $88.2 \%$ in our study. It is observed that vaccination rates among healthcare workers increased in recent years in Turkey ${ }^{15}$. This can be explained by the routine HBV screenings in healthcare workers and the implementation of protective measures.

It is estimated that the prevalence of Global $\mathrm{HCV}$ infection is about $2-3 \%$, although it is more common in developing countries ${ }^{16}$. According to Centers for Disease (CDC) data, it has been reported that 3.9 million individuals (1.8\%) have been contaminated with HCV and 2.7 million of these infections could become chronic ${ }^{17}$. Seroprevalence of Anti- HCV positivity in blood donors (n: 14354) was reported as $0.7 \%$ in our country ${ }^{7}$. There was no positivity in some of the studies investigating the seroprevalence of antiHCV in health workers $^{18,19}$. In recently, Anti- HCV positivity in healthcare workers in our country has been reported as $0.4 \%$ by Ozcimen et al ${ }^{11}$. And we have found anti-HCV positivity as $0.6 \%$ in our study.

Consequently, healthcare workers should be screened for HBV and HCV and individuals without HBV vaccination should be vaccinated. In our country, it is seen that HBsAg positivity in healthcare workers has decreased especially in recent years. Nevertheless, healthcare workers are under the risk of HBV and HCV. Therefore, it is important to keep and review the records of healthcare workers regularly. 
Declaration of Conflicting Interests: The authors declare that they have no conflict of interest.

Financial Disclosure: No financial support was received

\section{REFERENCES}

1. Askarian M, Yadollahi M, Kouchak F, et al. Precautions for Health Care Workers to Avoid Hepatitis B and C Virus Infection. Int J Occup Environ Med 2011;2:191-8.

2. Baumert TF, Meredith L, Ni Y, et al. Entry of hepatitis B and $C$ viruses recent progress and future impact. Curr Opin Virol 2014;4:58-65.

3. Shoaei P, Lofti N, Hassannejad R, et al. Seroprevalence of Hepatitis C Infection among Laboratory Health Care Workers in Isfahan, Iran. Int J Prev Med 2012;3:146-9.

4. Demir I, Kaya S, Demirci M, Cicioglu-Arıdogan B. Investigation of Seropositivity of Hepatitis B Virus in Healthcare Workers in Isparta,Turkey. Turkish Journal of Infection 2006;20:183-7.

5. Kader C, Yolcu S, Erbay A, et al. Investigation of Hepatitis B and C Seroprevelances in Bozok University School of Health Students. Viral Hepatitis Journal. 2012: 19;49-53.

6. Custer B, Sullivan SD, Hazlet TK, et al. Global epidemiology of hepatitis B virus. J Clin Gastroenterol. 2004; 38:158-68.

7. Girgin S, Temiz H, Gedik E, Gül K. Preoperative Seroprevalence of HBsAg, Anti-HCV, Anti-HIV in general surgery patients. Dicle Medical Journal 2009; 36:283-7.

8. Altındis M, Kocoglu F. An Investigation on the causative agents of viral infections in blood donors in Afyon region. Turk Hij Den Biyol Derg. 2001;58:61-6

9. Altındiş M, Aslan S, Kalaycı R. HBsAg, anti-HCV, antiHIV and syphilis seroprevalence in blood donors. Sakaryamj. 2011; 1:22-6
10. Tekay F, Ozbek E. Short communication: hepatitis B, hepatitis C and human immunodeficiency virus seropositivities in women admitted to Sanliurfa Gynecology and Obstetrics Hospital. Mikrobiyoloji bulteni 2006; 40:369-73.

11. Ozcimen S, Kacar F, Korkmaz F, et al. Seroprevalences of Hepatitis B and C among healthcare workers in Konya Research Training Hospital. Eur J Basic Med Sci 2014; 4:7-11

12. Bosnak KV, Karaoglan I, Namiduru M, Sahin A. Seroprevalences of Hepatitis B, Hepatitis C, HIV of the Healthcare Workers in the Gaziantep University Sahinbey Research and Training Hospital. Viral Hepatitis Journal. 2013; 19:11-4.

13. Akcalı A, Şener A, Tatman Otkun M, et al. Hepatitis B Seroprevalance Among Health care Workers in a Tertiary Hospital. Viral Hepatitis Journal. 2013;19:3640.

14. Korkmaz P, Cevik-Caglan F, Aykın N, et al. Seroprevalences of HBV, HAV, HCV and HIV Infection among Health Personnel in a State Hospital. Klimik Derg. 2013; 26:64-7.

15. Aydemir 0, Koroglu M, Yuksel B, et al. Lab BioSafety TR Working Group. Hepatitis B Virus Vaccination Rates among Medical Laboratory Workers: A Multi-centered Assessment. Viral Hepatitis Journal. 2016;22:82.

16. Lavanchy D. The global burden of hepatitis C. Liver Int. 2009; 29:74-81.

17. Centers for Disease Control and Prevention. Preרvention and control of infections with hepatitis virus in correctional setting. MMWR 2003;352:1-30.

18. Güzelant $A$, Kurtoğlu $M G$, Kaya $M$, et al. The seroprevalence of hepatitis B, hepatitis C and HIV in blood donors and workers in a dentistry center and risk factors for infection in blood donors. Turkish Journal of Infection 2008:22; 189-95.

19. Sarı N, Günal O, Dizbay M, et al. The Investigation of HBsAg and Anti-HCV Seroprevalence in Cleaning Staff and Nurse in a University Hospital. Viral Hepatitis journal 2006:11; 126-31. 